\title{
The role of RLAl in early schizophrenia treatment: critical aspects regarding efficacy and safety
}

\author{
George Papageorgiou \\ From $1^{\text {st }}$ International Congress on Neurobiology and Clinical Psychopharmacology and European \\ Psychiatric Association Conference on Treatment Guidance \\ Thessaloniki, Greece. 19-22 November 2009
}

It is well known that there are high levels of response to treatment topatients with a first episode and early schizophrenia. This outcome is hampered by inadequate treatment adherence, which leads to relapse, and high sensitivity to side-effects. Risperidone Long Acting Injectable (RLAI) treatment has proven to be advantageous compared to oral treatment to these early patients, both clinically and pharmacoeconomically. RLAI has proven to improve treatment adherence, prolong time to relapse vs. more chronically ill patients, to improve patient functioning and also to achieve better symptom control in comparison to oral haloperidol, risperidone and also to patients switched from oral olanzapine. Therefore, treatment with atypicals and especially with RLAI to first episode and early patients can alter favorably the course of the schizophrenic disorder.

Published: 22 April 2010

\section{References}

1. Olivares J-M, et al: Long-Term Outcomes in Patients with treat with Risperidone Long Acting Injection or oral antipsychotics in Spain:Results from the electronic Schizophrenia Treatment Adherence Registry (e_STAR). Europ Psychiatry 2009.

2. Lambert $\mathrm{T}$, et al: Risperidone Long Acting Injection in the Treatment of Recently vs. Longer Diagnosed Patients with Schizophrenia. Poster Presented at the 21st Congress of the European College of Neuropsychopharmacology, August 30 - September 3, 2008, Barcelona, Spain

Submit your next manuscript to BioMed Central and take full advantage of:

- Convenient online submission

- Thorough peer review

- No space constraints or color figure charges

- Immediate publication on acceptance

- Inclusion in PubMed, CAS, Scopus and Google Scholar

- Research which is freely available for redistribution 